\title{
TRANSFORMASI FUNGSI SIRING PADA RUMAH TRADISIONAL BUGIS DI BULUKUMBA
}

\author{
Zulkarnain AS ${ }^{1}$, Ahmad Ibrahim Rahmani ${ }^{2 *}$, Rahmat Wahidin AS $^{3}$ \\ Teknik Arsitektur, UIN Alauddin Makassar ${ }^{1,2,3}$ \\ e-mail: 1zoelarch@gmail.com, *2ahib.arsitek@gmail.com, ${ }^{3}$ rwahidin751@gmail.com
}

\begin{abstract}
Abstrak_ Penelitian ini ditujukan untuk mengidentifikasi perubahan fungsi maupun bentuk pada kolong rumah (siring) tradisional Bugis yang berprofesi sebagai nelayan, pembuat kapal dan petani di Bulukumba, serta memverifikasi mengenai perubahan bentuk dan wujud fisik siring yang terjadi seperti sekarang ini.Penelitian ini menggunakan metode deskriptif kualitatif dimana penelitian ini menggunakan sampel, wawancara, pengukuran dan data literatur sebagai pengumpulan data untuk penelitian ini.untuk mengetahui perubahan-perubahan bentuk dan fungsi apa saja yang terjadi pada siring khususnya pada rumah tradisional Bugis yang berprofesi sebagai nelayan, pembuat kapal dan petani. Dilakukan wawancara terhadap seorang narasumber yang berprofesi sebagai nelayan, seorang narasumber yang berprofesi sebagai pembuat kapal dan seorang narasumber yang berprofesi sebagai petani sebagai pemilik rumah tradisional Bugis.Untuk mengetahui perubahan yang terjadi dilakukan observasi dan penjelasan dari narasumber. Hasil penelitian menunjukkan bahwa perubahan yang terjadi ditinjau dari wujud fisik dan pola aktivitas yang terjadi antara lain yaitu terjadi perubahan wujud fisik, bentuk, fungsi dan pola aktivitas ruang siring pada rumah tradisional Bugis di Bulukumba terhadap bentuk aslinya.
\end{abstract}

Kata kunci : Bentuk; Fungsi; Pola Aktivitas; Siring; Rumah Tradisional.

\begin{abstract}
This research is intended to identify changes in the function or form of traditional Bugis under the house (siring) who work as fishermen, boat builders, and farmers in Bulukumba, as well as to verify the changes in the shape and physical form of siring that are happening today. This study uses a qualitative descriptive method where this study uses samples, interviews, measurements, and literature data as data for this study. to see what changes in form and function occur in the siring, especially in traditional houses, Bugis who work as fishermen, boat builders, and farmers in Bulukumba, as well as verifying regarding changes in the form and siring physical manifestation is happening today. This type of research qualitative, to determine changes in the shape and function of what is happening in the siring, especially in the traditional house Bugis living as fishermen, shipbuilders and farmers, conducted interviews with a resource person who work as fishermen, a resource person who worked as shipbuilders and a resource person who work as farmers as owners of traditional homes Bugis. To determine the changes made observations and explanations of sources. The results showed that the changes in terms of the physical form and activity patterns that occur include: $a$ ). siring form $b$ ). siring function c).pola activity. There were changes in physical form, shape, function, and activity patterns siring space in traditional houses Bugis in Bulukumba to its original form.
\end{abstract}

Keywords: Form; Function; Activity Pattern; Siring; Traditional House.

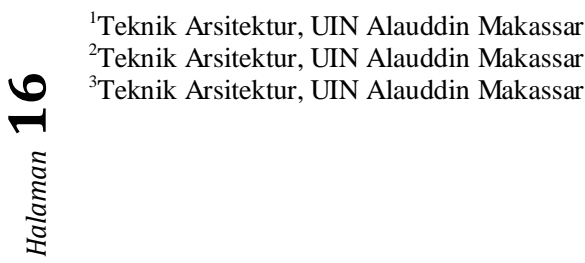




\section{PENDAHULUAN}

Sebagai sebuah hasil karya budaya, arsitektur telah menjadi salah satu cerminan kebudayaan dan kehidupan manusia pada satu wilayah dari masa ke masa.Seperti halnya arsitektur nusantara yang sangat terpengaruh oleh kepercayaan yang tercermin dalam tatanan ruang dan gubahan bentuk arsitekturnya.Gubahan bentuk pada arsitektur nusantara yang terinspirasi oleh alam dan menampilkan adaptasi yang kuat terhadap iklim dan lingkungannya.Khasanah bentuk arsitektur nusantara yang memiliki karakteristiknya sendiri-sendiri, demikian pula pada ornamen dan dekorasinya.Namun kekhasan bentuk dan tatanan arsitektur nusantara tersebut telah mengalami banyak transformasi.

Secara tipologi-geometri, transformasi bentuk maupun tatanan bangunan dapat dilihat dari bagaimana perubahan bentuk geometri dengan komponen pembentuk dan fungsi ruang ke bentuk baru yang kurang lebih serupa.Sementara itu dalam kategori lainnya juga terdapat transformasi gramatika yang menggeser, memutar dan mencerminkan objek serta transformasi yang lebih bersifat mendistorsi (Soewarno, 2020).

Arsitektur sebagai wadah pemenuhan kebutuhan terhadap aktivitas manusia diharapkan dapat memenuhi fungsinya dengan baik, namun fungsi juga dapat mengalami transformasi dan berkembang terus-menerus sesuai kebutuhan dan zamannya, bentuk akan berubah jika fungsi berubah dan fungsi baru tidak mungkin mengikuti bentuk lama, (Ching, 1999). Perubahan wujud pada bangunan adalah salah satu respon arsitektur terhadap pergeseran fungsi dan aktivitas yang terjadi pada ruang.

Rumah tradisional Bugis Makassar di Bulukumba tidak luput dari perubahan baik secara wujud, fungsi maupun tatanannya terutama pada bagian kolong rumah (Siring).Adapun perbedaan dan perubahan yang terjadi pada siring dikarenakan adanya faktor-faktor tertentu yang menyebabkan hal tersebut terjadi. Faktor- faktor yang menyebabkan proses perubahan fungsi dan wujud ruang itu adalah ekonomi, politik, sosial dan kultural atau disebut transformasi sosio-spasial (Debby \& Dewi, 2019). Kolong rumah (Siring) menurut kepercayaan/pemahaman yang mengilhami masyarakat bugis jauh sebelum islam masuk ke Sulawesi bahwa dunia terbagi atas 3 bagian yaitu dunia atas, dunia tengah dan dunia bawah. Dari itulah masyarakat beranggapan bahwa dunia bawah (Siring) tidak difungsikan sebagai tempat untuk ditinggali karena menurut pemahaman mereka tempat tersebut diperuntukkan untuk hewan ternak dan tempat yang kotor.

Seiring perkembangan zaman yang begitu kuat mengakibatkan pemikiran masyarakat yang awalnya berpedoman kepada budaya-budaya atau kepercayaan leluhur mereka kini lebih mengarah kepada perkembangan zaman modern, dalam hal ini yang berkaitan dengan bentuk dan fungsi pada kolong rumah tradisional Bugis-Makassar di Bulukumba.Tidak bisa dielakkan penambahan jenis aktivitas baru pada beberapa rumah tentu saja berpengaruh pula pada pola aktivitas penghuni rumah ini yang disebut Behaviour Modifier (Nurhuzna, 2017).

Sebuah bangunan adalah produk dari fungsinya, bangunan yang baik adalah yang dapat memfasilitasi atau mewakili tujuan yang dimaksudkan untuk bangunan tersebut. Meskipun tujuan lain suatu elemen arsitektur adalah estetika. Namun dalam konteksnya estetika itu sendiri, suatu desain tidak dapat dibatasi pada ukuran, bentuk dan proporsinya tetapi memerlukan makna praktisnya yaitu fungsi (Emmanuel Arenibafo, 2017). Umumnya rumah-rumah tradisional BugisMakassar di Bulukumba sebagian telah direnovasi akan tetapi masih menyisakan beberapa unsur yang dianggap penting oleh masyarakat, akan tetapi siring pada rumah tradisional bugis di 
Bulukumba mengalami transformasi fungsi yang tergolong unik dan berbeda dengan yang lainya, sehingga dibutuhkan kajian khusus terhadap proses transformasi fungsi ini.

Area yang sering kali mengalami transformasi komposisi ruang adalah area ruang komunal berupa penambahan fungsi atau tatanan bangunan.Faktor utama penyebab transformasi terdiri dari kepercayaan dan adat istiadat setempat, kebutuhan ruang, sumber dan tingkat perekonomian serta lokasi strategis (Dewi, 2014). Disamping itu, penelitian ini diupayakan agar diperoleh deskripsi tambahan, yaitu gambaran tentang hubungan dan perbedaan antara masyarakat BugisMakassar di Bulukumba yang berprofesi sebagai pembuat kapal, nelayan dan petani di lokasi Bonto Bahari yaitu di Kelurahan Tanah Lemo, Bulukumba Sulawesi Selatan.

Permasalahan pokok yang ingin dipecahkan pada penelitian ini adalah, bagaimana fungsi dari siring pada rumah bugis di bulukumba ini mengalami transformasi, oleh karena itu penelitian bertujuan untuk mengidentifikasi perubahan tatanan, bentuk dan fungsi yang terjadi pada siring di bangunan rumah tradisional Bulukumba yang sudah tak sesuai dengan yang semestinya, sehingga menggeser niali-nilai budaya yang melekat pada rumah tradisional di bulukumba.

\section{METODE}

Metode yang digunakan peneliti dalam penelitian ini adalah jenis penelitian kualitatif, Moleong (1994) mengatakan bahwa metode kuantitatif adalah metode pengambilan data yang menghasilkan data deskriptif berupa kata-kata yang tertulis dan lisan dari orang-orang dan perilaku masyarakat yang dapat diamati. Sedangkan metode penelitian kualitatif adalah proses penelitian dan pemahaman yang berdasarkan pada metode yang menyelidiki suatu fenomena sosial dan masalah manusia yang terjadi, kemudian membuat sebuah gambaran kompleks dan melakukan suatu studi mengenai situasi yang terjadi.

Karena pada penelitian ini dilakukan dengan mengumpulkan data yang diperlukan serta berkaitan dengan permasalahan berdasarkan fakta dan gejala di lapangan, kemudian menerapkan dan menyampaikannya dalam metode deskriptif. Selain itu metode Eksplanatif juga dilakukan dengan menerangkan/ menjelaskan latar belakang atau alasan-alasan kejadian/gejala/fenomena kenyataan situasi tersebut dengan cara mengaitkan teori-teori dan empirisme.

Metode deskriptif, (Mardalis 1999). Bertujuan untuk mendeskripsikan apa yang saat ini sedang berlaku. Didalamnya terdapat upaya mendeskripsikan, mencatat, menganalisis dan menginterpretasikan kondisi yang sekarang ini yang sedang terjadi atau ada.Penelitian ini tidak menguji hipotesis ataupun menggunakan hipotesa.

Penelitian ini menggunakan pendekatan rasionalistik dengan metode penelitian deskriptif dimana sample, wawancara, pengukuran dan data literatur sebagai pengumpulan data untuk penelitian ini.Teknik sampling yang digunakan adalah purposive sampling. Menurut Mardalis (1999) teknik ini mempunyai tujuan atau dilakukan dengan sengaja, cara menggunakan sampel ini di antara populasi sehingga sampel tersebut dapat mewakili karakteristik populasi yang dikenal sebelumnya. 


\section{HASIL DAN PEMBAHASAN}

\section{A. Lokasi Penelitian}

Bulukumba adalah salah satu kabupaten di daerah Provinsi Sulawesi Selatan, Indonesia. Ibu kotanya terletak di Kota Bulukumba.Bulukumba memiliki luas wilayah $1.154,67 \mathrm{~km}^{2}$ dengan jumlah penduduk sebanyak 394.757 jiwa (berdasarkan sensus penduduk 2010).Kabupaten Bulukumba mempunyai 10 kecamatan, 24 kelurahan, serta 123 desa.Secara topografi Bulukumba berada pada kondisi empat dimensi, yakni dataran tinggi pada kaki Gunung Bawakaraeng- Lompobattang, dataran rendah, pantai dan laut lepas.Luas wilayah Kabupaten Bulukumba 1.154,67 Km2 dengan jarak tempuh dari Kota Makassar sekitar 153 $\mathrm{Km}$.

Kecamatan Bonto Bahari adalah salah satu wilayah kecamatan di Kabupaten Bulukumba, terletak paling ujung selatan dari Pulau Sulawesi dengan ibu kota Tanah Beru. Kecamatan Bonto Bahari terdiri atas 4 Wilayah Desa dan 4 Kelurahan yang meliputi: 1.Desa Ara, 2.Desa Bira, 3.Desa Darubiah, 4.Desa Lembanna. serta 1.Kelurahan Benjala, 2.Kelurahan Sapolohe, 3.Kelurahan Tanah Beru, 4.Kelurahan Tanah Lemo. Lokasi penelitian ini mengambil objek di Kelurahan Tanah Lemo, Kecamatan Bonto Bahari Kabupaten Bulukumba Sulawesi selatan.Berikut lokasi penelitian disajikan pada gambar dibawah ini:

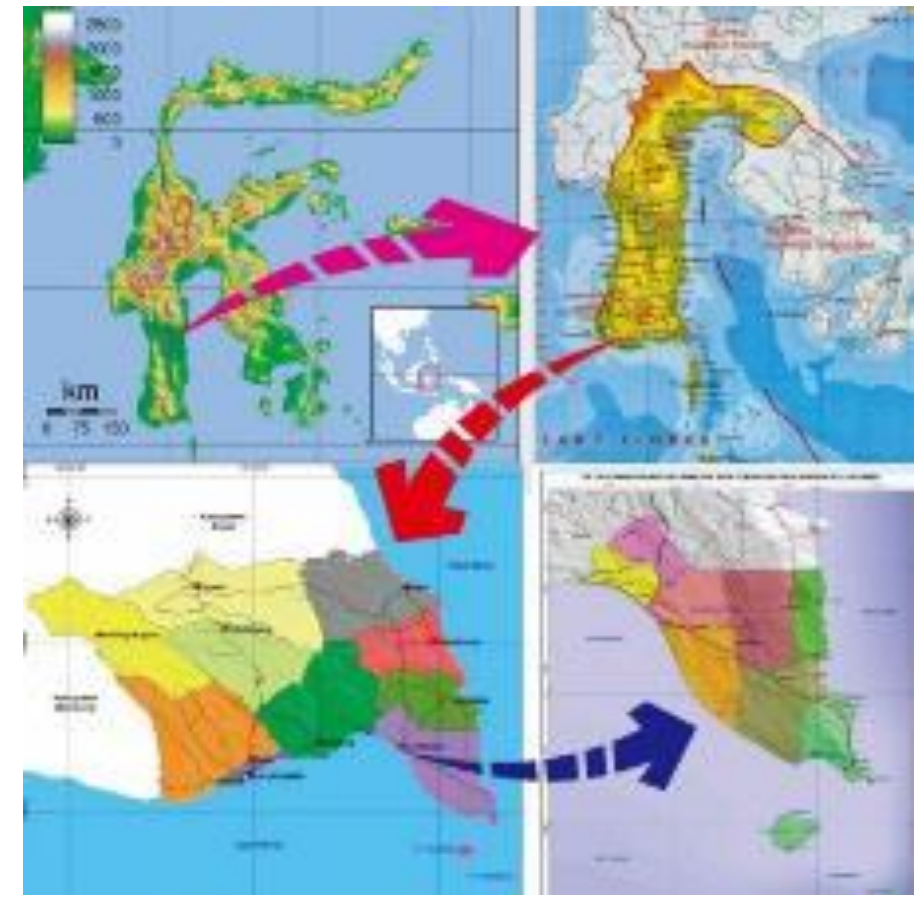

Gambar 1.Peta Sulawesi, Sulawesi-selatan, Kabupaten Bulukumba dan Kecamatan Bonto Bahari. Sumber: http://petatematikindo.files.wordpress.com/2013/02/administrasi-b ontobahari1.jpg, 2020

\section{B. Rumah Tradisional Bugis}

Masyarakat tradisional Bugis memiliki pandangan hidup ontologism, yakni bagaimana hidup di alam semesta secara universal.Filosofi hidup masyarakat tradisional Bugis yang disebut Sulapa Appa Ini kemudian tercermin dalam konsep arsitektur rumah tradisional bugis yang menunjukkan upaya untuk menyempurnakan diri.Filosofi ini menyatakan bahwa segi empat sebagai bentuk sempurna dari segala aspek kehidupan manusia. Filosofi yang bersumber dari mitos asal mula kejadian manusia yang diyakini terdiri dari empat unsur, yaitu: 
tanah, air, api dan angin. Bagi masyarakat tradisional Bugis yang berpikir secara totalitas, maka rumah tradisional Bugis dipengaruhi pemahaman struktur kosmos, dimana alam terbagi atas tiga bagian, yaitu: alam atas, alam tengah dan alam bawah (Tato, 2009:8).

Hal ini lah yang mendasari mengapa persegi Panjang telah menjadi ciri khas rumah panggung kayu merupakan ciri khas tampilan rumah tradisional Bugis. Bentuk rumah panggung kayu pada umumnya merupakan rumah yang terdiri dari beberapa tiang-tiang untuk menahan beban lantai dan atap bagian rumah. Ciri khas rumah Bugis yang memiliki kolong rumah sangat nyaman digunakan untuk beristirahat ketika di siang hari.Konstruksi rumah Bugis didominasi dengan penggunaan material kayu dan berdiri dengan menggunakan sistem pasak (Hatta \& Sudradjat, 2020).

Rumah tradisional orang Bugis tersusun dari tiga tingkatan yang berbentuk segi empat dibentuk dan dibangun mengikuti model kosmos menurut pandangan hidup mereka, anggapannya bahwa alam raya (makrokosmos) ini tersusun dari tiga tingkatan, yaitu: alam atas atau banua atas, alam tengah atau banua tengah dan alam bawah atau banua bawah. Banua atas adalah tempat dewa-dewa yang dipimpin oleh seorang dewa tertinggi yang disebut Dewata Seuwae (dewa tunggal) yang bersemayam di botting langi' (langit tertinggi).Banua tengah adalah bumi ini dihuni pula oleh wakil-wakil dewa tertinggi yang mengatur hubungan manusia dengan dewa tertinggi serta mengawasi jalannya tata tertib kosmos. Banua bawah disebut juga Utility (tempat paling dalam) dianggap berada di bawah air.Semua pranata-pranata yang berkaitan dengan pembuatan atau pembangunan rumah harus berdasarkan kosmologis yang diungkapkan dalam bentuk makna simbolis filosofis, yang diketahuinya secara turun temurun (Abu Hamid, 1978:30-31),

Dilihat dari segi vertikal, rumah tradisional Bugis dibagi atas 3 (tiga) bagian, berdasarkan pada kepercayaan masyarakat Bugis tentang adanya istilah tiga dunia, yaitu dunia atas, dunia tengah dan dunia bawah yang diaplikasikan pada rumah, yaitu:

1. Rakkeang, terletak pada bagian atas rumah (dunia atas). Pada bagian ini terdiri atas atap dan plafon. Berfungsi sebagai gudang penyimpanan padi sebagai lumbung kehidupan/kesejahteraan pemiliknya. Dan untuk loteng bagian depan dimanfaatkan untuk menyimpan benda pusaka atau benda-benda sebagai atribut adat kebesaran.

2. Ale Bola, terletak pada bagian tengah rumah (dunia tengah). Di bagian ini ada sebuah tiang yang ditonjolkan daripada tiang yang lainnya. Ruangannya terbagi atas beberapa petak dengan masing-masing fungsinya. Area ini menjadi pusat aktivitas berinteraksi antar anggota keluarga. Pada ale bola terdapat ruang-ruang yang dipergunakan dalam kehidupan sehari-hari, seperti: menerima tamu, tidur, musyawarah dan tempat menyimpan. Pada dasarnya ruangan-ruangan ini berbentuk persegi empat yang dibatasi oleh dinding. Tiangtiang yang ada di rumah ini selain menyanggah berdirinya rumah, juga sebagai tempat memasang dinding.

3. Awaso/awa bola, terletak pada bagian bawah rumah (dunia bawah). Bagian ini dimanfaatkan sebagai tempat menyimpan alat-alat melaut, pertanian, pertukangan dan kandang ternak ataupun sebagai tempat perahu untuk rumah pesisir. 


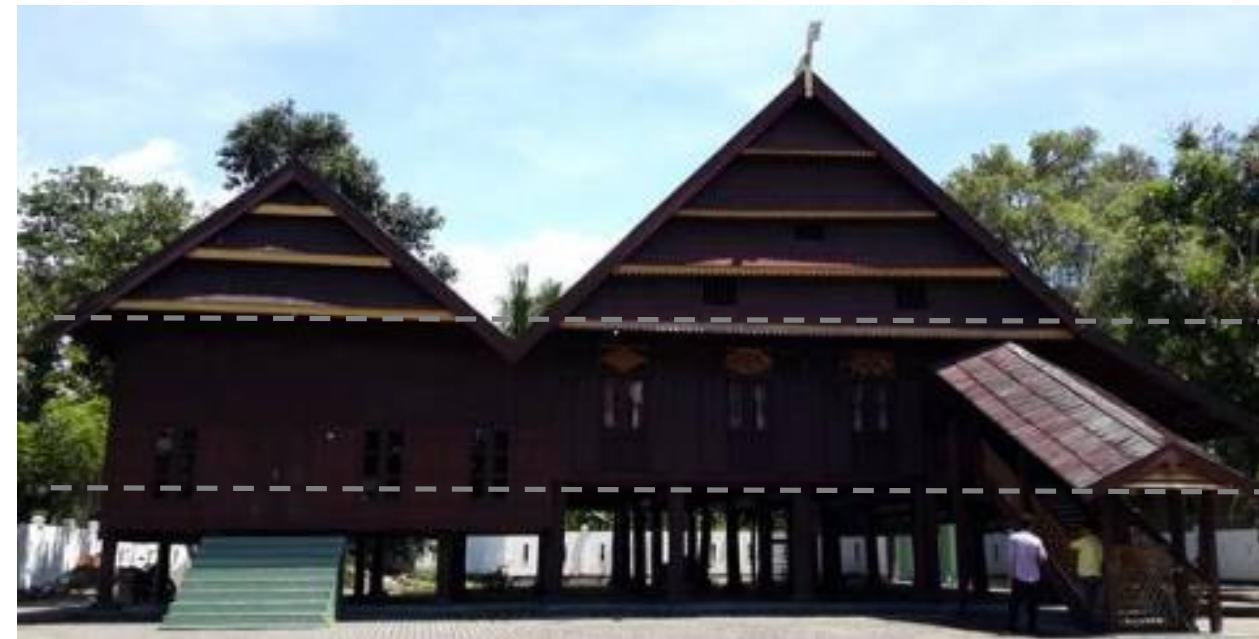

Gambar 2.Rumah tradisional Bugis tampak depan dan samping Sumber: https://satujam.com, 2020

\section{Rakkeang}

Tempat

penyimpanan padi

(dunia atas)

\section{Ale'Bola}

Ruang tempat tinggal (dunia)

\section{Awa'Sao'/Awa'}

Bola

Ruang bawah

(Dunia bawa)

Rumah bagi masyarakat bugis sebagai makhluk yang memiliki proses kehidupan, dalam konsepsi Bugis sering disebut dengan "Sulapa eppa" atau belah ketupat. Pola persegi empat panjang (belah ketupat) sering juga disimbolkan sebagai empat penjuru mata angin.

Bentuk rumah yang dijumpai di Kawasan pesisir Bulukumba yang terletak di kelurahan Tanah Lemo secara keseluruhan memiliki keseragaman memiliki bentuk rumah panggung. Rumah tradisional bugis yang berbentuk panggung ini memiliki tiang (benteng) yang ditanam/ditenggelamkan ujung bagian bawahnya ke dalam tanah. Secara struktural tiang-tiang ditanam kedalam tanah, maka cukup kuat menahan/melawan gaya-gaya beban horizontal dengan posisi tiang yang bengkok.

\section{Hasil Survei}

\section{Siring Rumah Tradisional Masyarakat Bugis di Bulukumba yang berprofesi sebagai Pembuat Kapal}

Dari segi bentuk rumah terdapat dimensi oleh masyarakat bugis yang merupakan perwujudan dari tubuh manusia yaitu bentuk secara. Secara vertikal terdiri atas Ata' (atap) yang merupakan perwujudan dari kepala pada manusia, kale balla' (badan rumah) yang merupakan perwujudan dari badan manusia dan siring (kolong rumah) yang merupakan perwujudan dari kaki pada manusia. Konsep yang akan dikaji dalam hal ini adalah orientasi wujud fisik dan pola aktivitas di ruang Siring pada rumah tradisional Bugis nelayan, pembuat kapal dan petani di Bulukumba. 


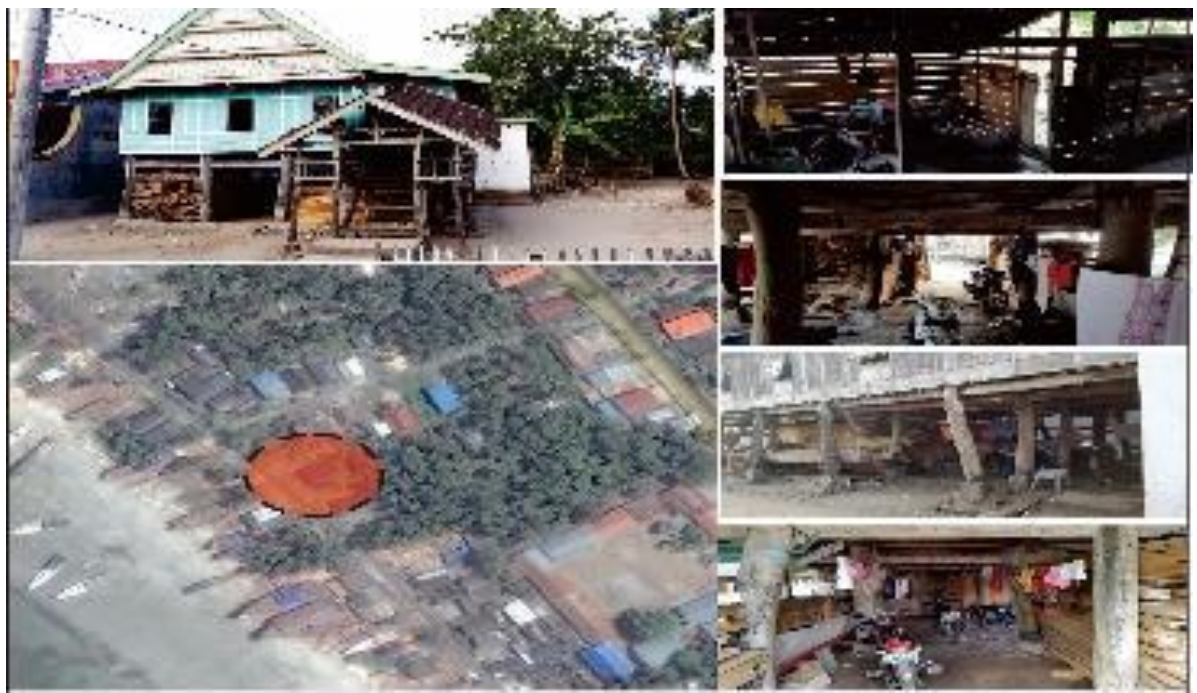

Gambar 3. Sampel 1: Tampilan (fasad),lokasi dan pemanfaatan kolong rumah pembuat kapal Sumber : Dokumentasi Pribadi, 2020

\section{a. Karakteristik Wujud Fisik}

Sampel pertama yaitu siring pada rumah tradisional masyarakat Bugis di Bulukumba yang berprofesi sebagai pembuat kapal.Dimana bentuk rumahnya yaitu empat persegi panjang dengan ukuran $8.79 \mathrm{~m} \times 13.02 \mathrm{~m}$ dengan menggunakan bahan kayu dan beton. Pengaplikasian warna coklat terdapat pada kolom kayu, balok kayu, tangga kayu, pintu kayu, dan dinding kayu. Sedangkan pengaplikasian warna putih terdapat pada dinding beton dan pondasi beton.Pada kolom kayu, balok kayu, tangga kayu, pintu kayu, dan dinding kayu tekstur yang dimiliki yaitu berserat \& kasar.Sedangkan pada dinding beton dan pondasi beton memiliki tekstur rata dan kasar.

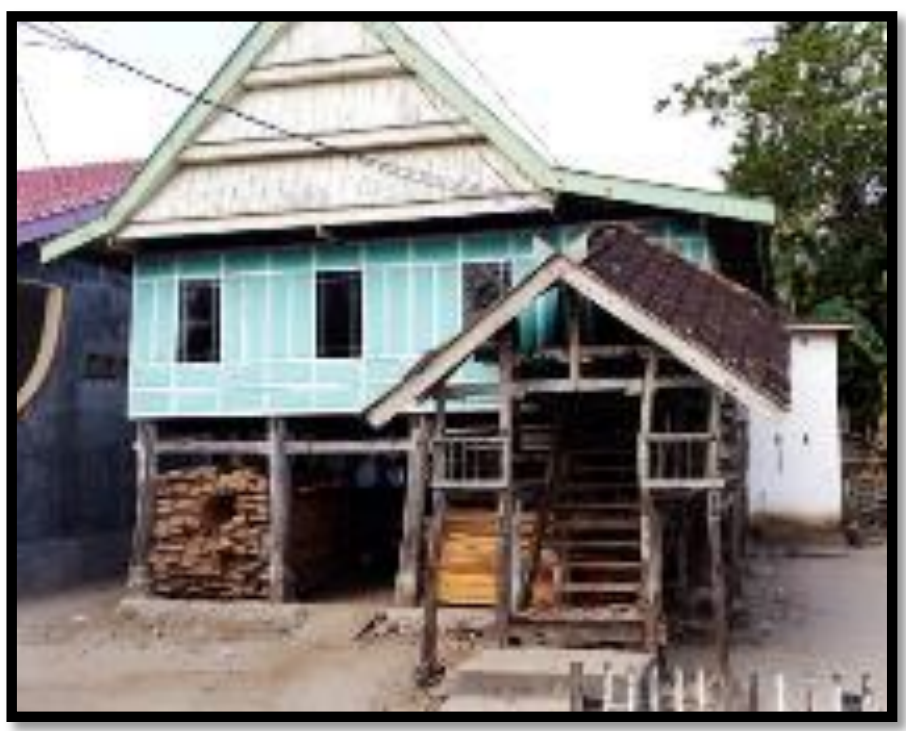

Gambar 4.Sampel 1, Tampilan kolong rumah pembuat kapal Sumber : Dokumentasi Pribadi, 2020 


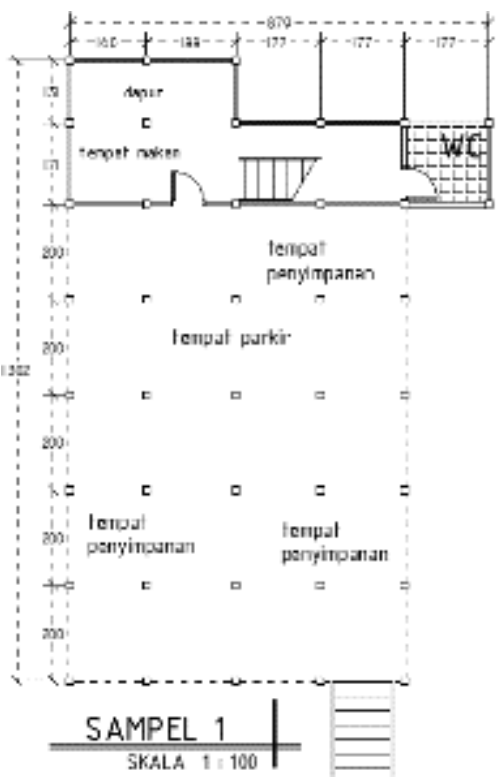

Gambar 5. Sampel 1, Denah kolong rumah pembuat kapal Sumber : Data Pribadi, 2020

\section{b. Pola Aktivitas Dan Pemanfaatan Ruang Siring}

Dari hasil analisis penulis terhadap pemanfaatan siring seperti pada gambar uraian waktu aktivitas di bawah, penulis menyimpulkan bahwa ayah hanya berada di ruang siring pada istirahat antara jam 12:00 - 13:00 dan melakukan pekerjaan sambilan (Panjamaang) antara jam 17:00 - 18:00, ibu berada di ruang siring antara jam 07:00 08:30 dan 16:00 - 17:00 untuk membersihkan, 09:30 - 10:30 untuk menjemur (Pappangingang), dan memasak (Pappaluang) antara 05:30 - 06:30, sedangkan orang lain hanya datang untuk memarkirkan kendaraannya (Bara motoro).

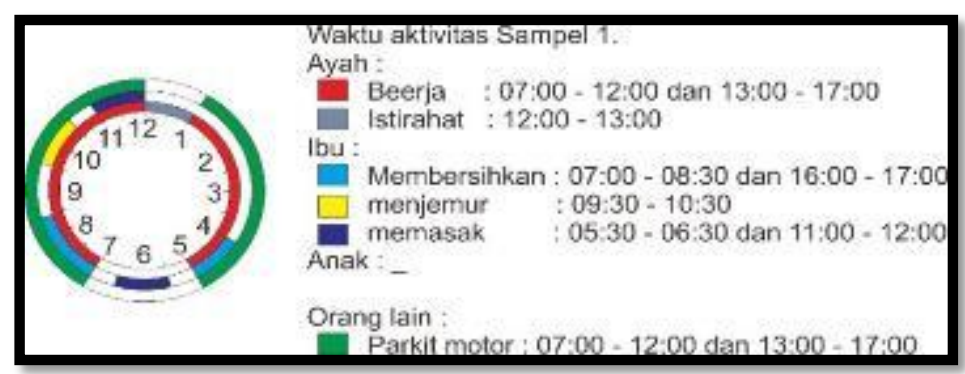

Gambar 6. Sampel 1, Pola aktivitas dan pemanfaatan kolong rumah pembuat kapal Sumber : Data Pribadi, 2020

\section{c. Pemanfaatan Siring Dulu dan Sekarang}

Karakteristik Siring pada rumah tradisional Bugis di Bulukumba ini antara waktu terdahulu/awal pembuatan rumah dan sekarang, terdapat beberapa perubahan yang telah terjadi seperti pemanfaatan siring dulunya hanya sebagai tempat penyimpanan hasil dan alat-alat melaut dan tempat bekerja. Namun saat ini digunakan sebagai tempat penyimpanan alat-alat dan bahan-bahan pembuatan kapal, tempat bekerja, tempat menjemur, dapur, wc, dan parkir. Dari hasil wawancara penulis, narasumber menjelaskan bahwa faktor utama yang mempengaruhi terjadinya perubahan fungsi pada siringadalah faktor fungsional atau pemanfaatan ruang-ruang yang kosong agar lebih bermanfaat. 
2. Siring Rumah Tradisional Masyarakat Bugis di Bulukumba yang berprofesi sebagai Petani
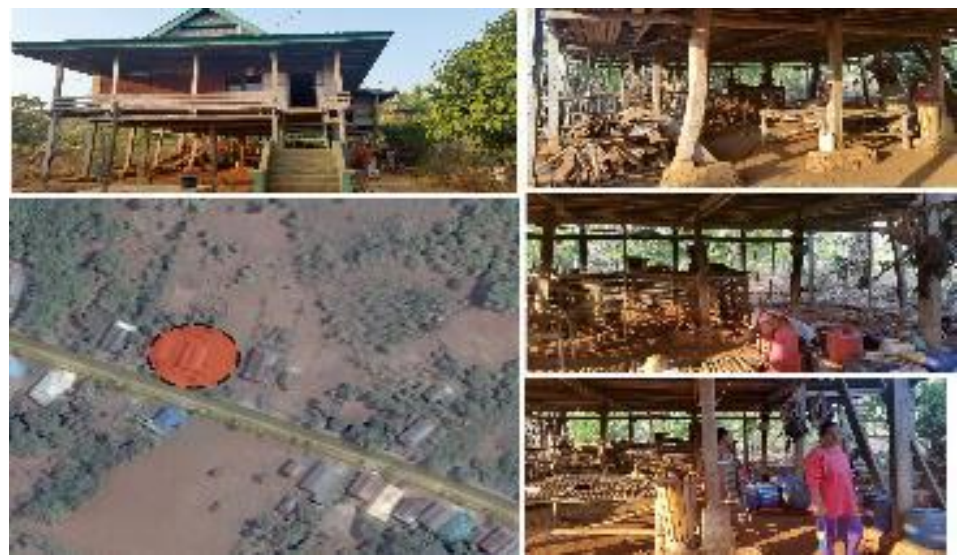

Gambar 7. Sampel 2, Tampilan (fasade), Lokasi Dan Pemanfaatan Kolong Rumah Petani Sumber : Dokumentasi Pribadi, 2020

\section{a. Karakteristik Wujud Fisik}

Sampel kedua yaitu siring pada rumah tradisional masyarakat Bugis di Bulukumba yang berprofesi sebagai petani.Dimana bentuk rumahnya yaitu empat persegi panjang dengan ukuran $10 \mathrm{~m}$ x $14 \mathrm{~m}$ dengan menggunakan bahan kayu, dan beton.Pengaplikasian warna coklat terdapat pada kolom, balok, dinding kayu, dan tangga kayu. Sedangkan pengaplikasian warna putih terdapat pada tangga beton.Pada kolom, balok, dinding kayu, dan tangga kayu tekstur yang dimiliki yaitu berserat \& kasar.Sedangkan pada tangga beton memiliki tekstur rata dan kasar.

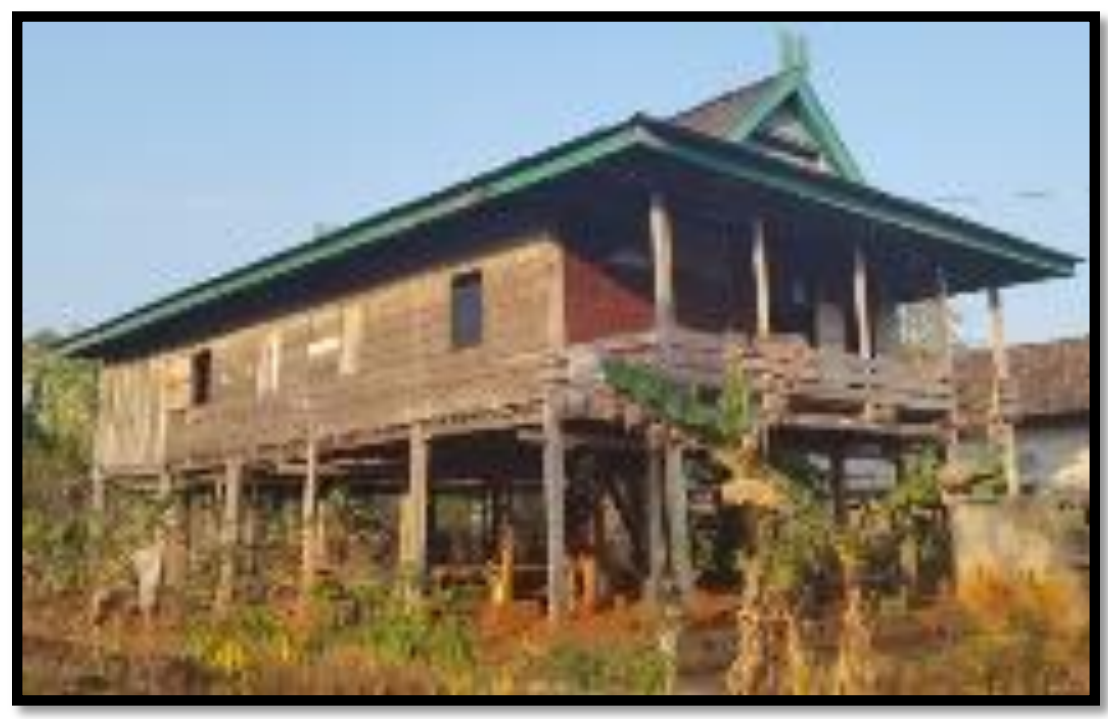

Gambar 8.Sampel 2: Tampilan (fasad) Kolong Rumah Petani Sumber : Dokumentasi Pribadi, 2020 


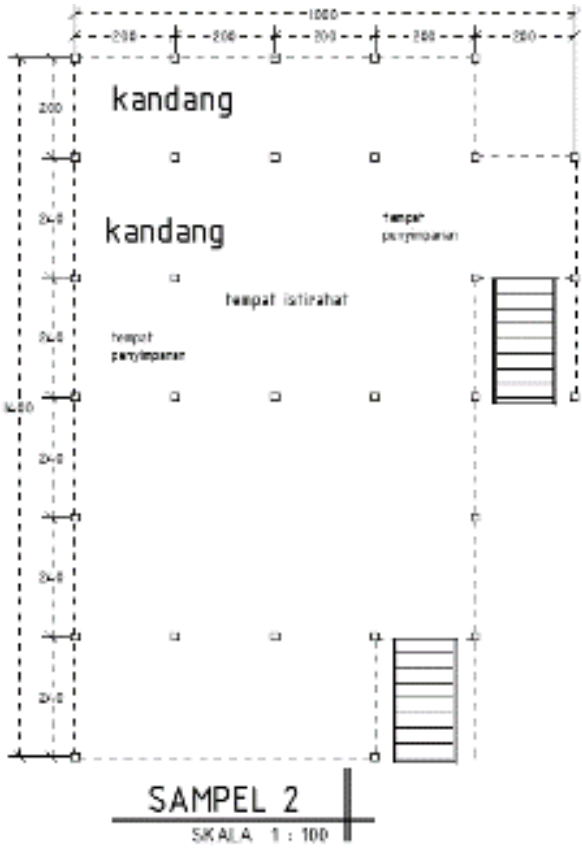

Gambar 9. Sampel 2: Denah Kolong Rumah Petani Sumber : Data Pribadi, 2020

\section{b. Pola Aktivitas dan Pemanfaatan Ruang Siring}

Dari hasil analisis penulis terhadap pemanfaatan siring seperti pada gambar uraian waktu aktivitas di bawah, penulis menyimpulkan bahwa ayah hanya berada di ruang siring saat beristirahat setelah dari kebun pada jam 11:00 - 13:00 dan melakukan aktivitas tambahan lainnya seperti beternak (bara jangang) pada jam 17:00 - 18:00. Ibu hanya berada di ruang siring antara jam 08:30 - 16:00 dan 17:00 - 18:00 untuk beristirahat (sarigang)sehabis bekerja di ladang, membersihkan dan melakukan aktivitas tambahan lainnya (pappangingang) dan anak berada di ruang siring antara jam 11:00 - 13:00 untuk bermain dan beristirahat serta melakukan aktivitas tambahan lainnya antara jam 16:30 - 18:00.

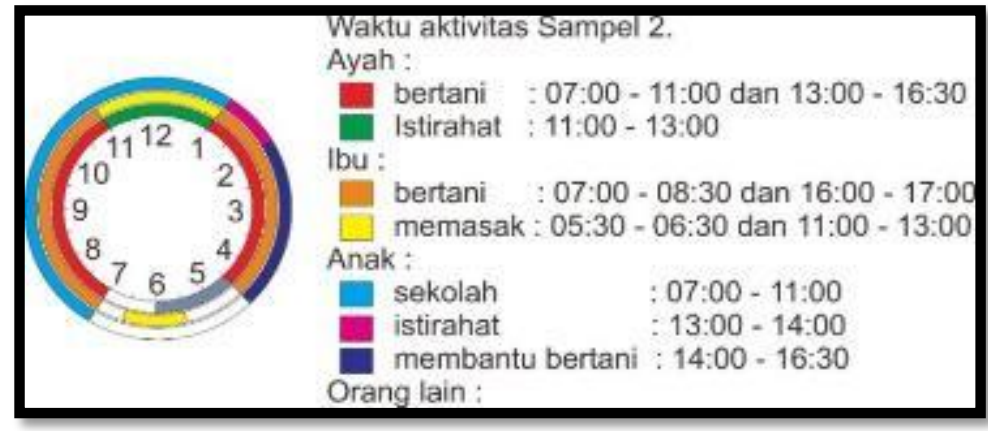

Gambar 10.Sampel 2, PolaAktivitas dan Pemanfaatan Kolong Rumah Petani Sumber : Data Pribadi, 2020

\section{c. Pemanfaatan Siring Dulu dan Sekarang}

Pemanfaatan siring dulunya hanya sebagai tempat penyimpanan alat-alat dan hasil pertanian, tempat menjemur, dan kandang hewan. Namun saat ini digunakan sebagai tempat penyimpanan alat-alat dan hasil pertanian, tempat menjemur, kandang hewan, 
tempat istirahat, dan tempat usaha. Dari hasil wawancara penulis, narasumber menjelaskan alasan mereka merubah fungsi siring dari yang sebelumnya karena faktor kenyamanan melakukan aktivitas di siring tersebut dan juga alasanya ingin memanfaatkan ruang-ruang pada siring yang kosong.

\section{Siring Rumah Tradisional Masyarakat Bugis di Bulukumba yang berprofesi sebagai} Nelayan
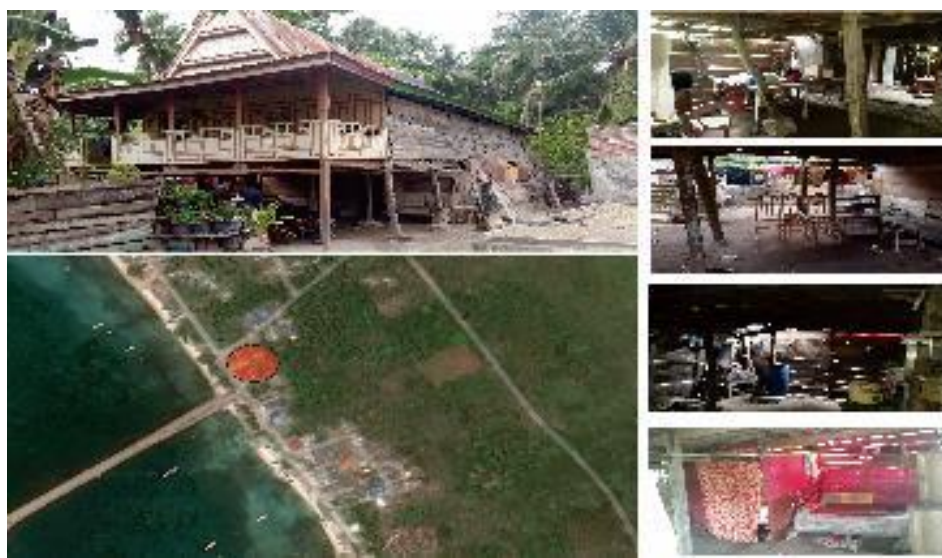

Gambar 11. Sampel 3, Tampilan (fasad), Lokasi dan Pemanfaatan Kolong Rumah Nelayan Sumber : Dokumentasi Pribadi, 2020

\section{a. Karakteristik Wujud Fisik}

Sampel ketiga yaitu siring pada rumah tradisional masyarakat Bugis di Bulukumba yang berprofesi sebagai nelayan.Dimana bentuk rumahnya yaitu empat persegi panjang dengan ukuran $7.48 \mathrm{~m} \times 15.07 \mathrm{~m}$ dengan menggunakan bahan kayu, beton, dan bambu.Pengaplikasian warna coklat terdapat pada kolom, balok, dinding kayu, tangga kayu, pintu kayu, jendela kayu, dan dinding bambu. Sedangkan pengaplikasian warna putih terdapat pada dinding beton dan tangga beton. Pada kolom, balok, dinding kayu, tangga kayu, pintu kayu, jendela kayu, dan dinding bambu tekstur yang dimiliki yaitu berserat \& kasar. Sedangkan pada dinding beton dan tangga beton memiliki tekstur rata dan kasar.

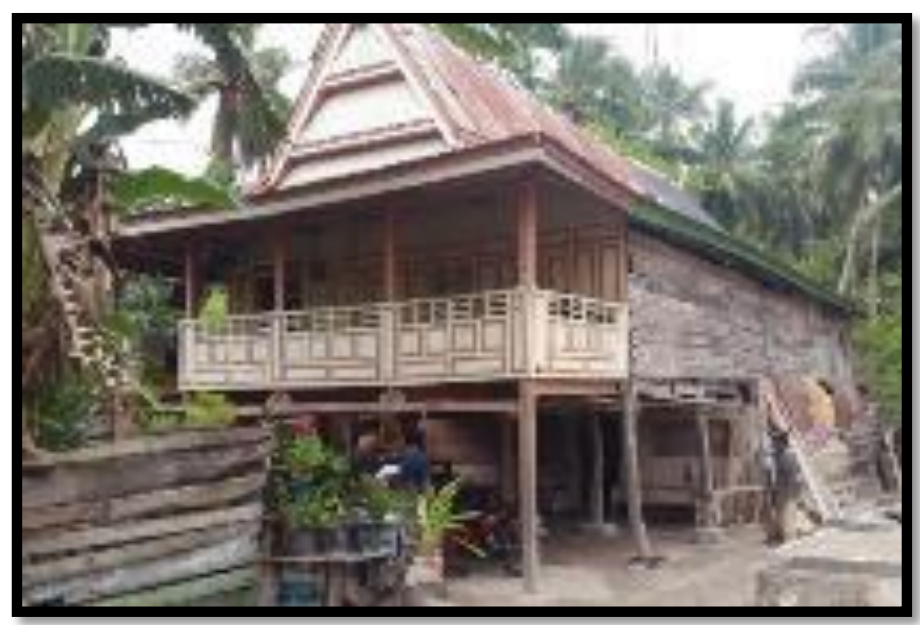

Gambar 12. Sampel 3: Tampilan (fasad) Kolong Rumah Nelayan Sumber : Dokumentasi Pribadi, 2020 


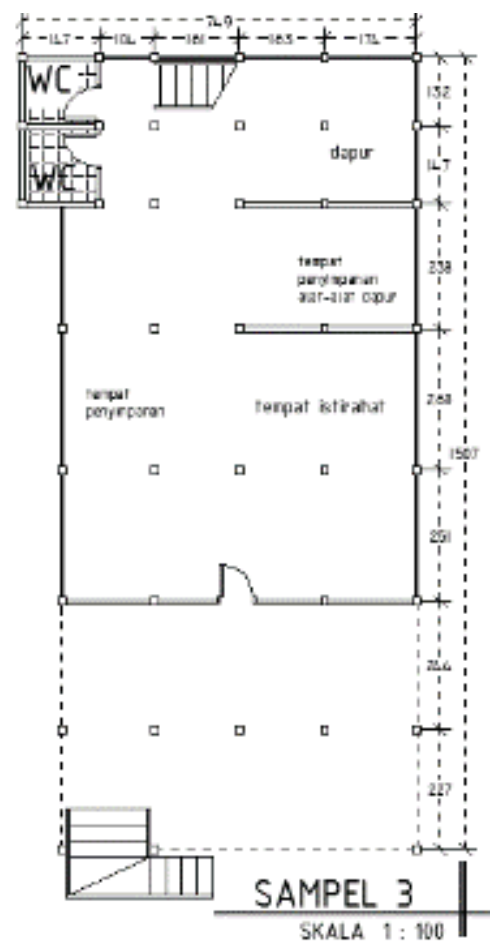

Gambar 13.Sampel 3: Denah Kolong Rumah Nelayan Sumber : Data Pribadi, 2020

\section{b. Pola Aktivitas Dan Pemanfaatan Ruang Siring}

Dari hasil analisis penulis terhadap pemanfaatan siring seperti pada gambar uraian waktu aktivitas di bawah, penulis menyimpulkan bahwa ayah hanya berada di ruang siring pada jam 17:00 - 11:00 dan 13:00 - 17:00 untuk melakukan persiapan sebelum melaut seperti memperbaiki jaring (Panjamaang)dan lain-lain. Jam 11:00 - 13:00 digunakan untuk beristirahat (sarigang)dan melakukan aktivitas tambahan lainya. Ibu hanya berada di ruang siring antara jam 07:00 - 09:00 untuk membersihkan dan melakukan pekerjaan-pekerjaan tambahan seperti menjemur (Pappangingang) dan lain-lain.

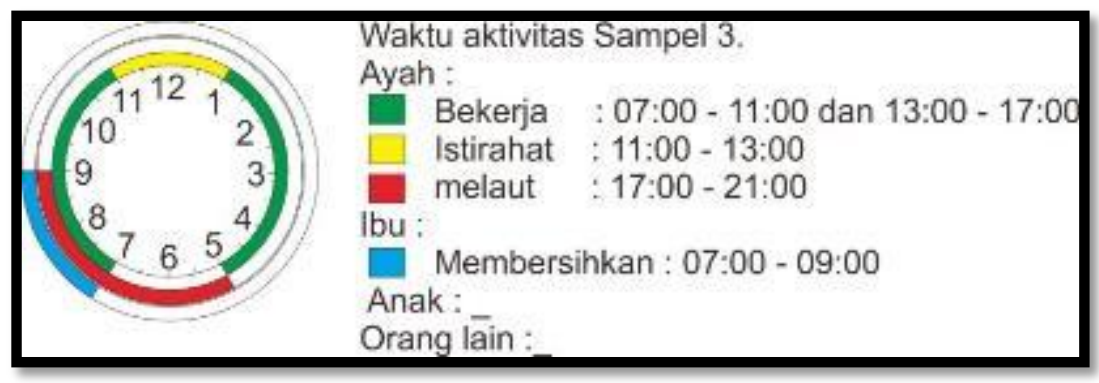

Gambar 14. Sampel 3, Pola aktivitas dan pemanfaatan kolong rumah nelayan Sumber : Data Pribadi, 2020

\section{c. Pemanfaatan Siring Dulu dan Sekarang}

Pemanfaatan siring dulunya hanya sebagai tempat penyimpanan hasil dan alat-alat melaut, tempat menjemur, dan tempat bekerja. Namun saat ini digunakan sebagai 
tempat penyimpanan hasil dan alat-alat melaut, tempat menjemur, tempat bekerja, tempat istirahat, dapur, wc, dan tempat penyimpanan. Dari hasil wawancara penulis, narasumber menjelaskan alasan mereka merubah fungsi siring dari yang sebelumnya karena faktor kenyamanan melakukan aktivitas di siring tersebut dan juga alasanya ingin memanfaatkan ruang-ruang pada siring yang kosong.

\section{Pembahasan}

Berdasarkan hasil survei diatas dari tiga sampel siring pada tiga rumah tradisional BugisBulukumba dengan profesi penghuni yang berbeda-beda terdapat beberapa pembahasan dari segi bentuk fisiknya, pola aktivitasnya, dan pemanfaatannya.Dari segi bentuk pada ketiga sampel tidak memiliki perbedaan yang signifikan baik dari bentuk denah maupun dari segi penggunaan bahannya.Ketiga sampel siring berbentuk empat persegi panjang dengan ukuran yang berbeda dan bahannya masih dominan menggunakan bahan alami seperti kayu dan papan.Namun ada beberapa bagian yang sudah menggunakan bahan modern seperti beton. Sedangkan pengamatan pada pola aktivitas dalam pemanfaatan ruang siring yang terjadi pada ketiga sampel menunjukkan bahwa selain fungsi utama ruang siring sebagai tempat penyimpanan alat terdapat aktivitas-aktivitas tambahan seperti tempat parkir, tempat menjemur, tempat usaha, dan tempat untuk beristirahat. Karakteristik Siring pada rumah tradisional Bugis di Bulukumba antara waktu terdahulu/awal pembuatan rumah dan sekarang, terdapat beberapa perubahan yang telah terjadi dan memunculkan perbedaan. Dari hasil analisis penulis menjelaskan kolong rumah (siring) tradisional masyarakat Bugis di Bulukumba yang berprofesi sebagai nelayan, pembuat kapal dan petani menunjukan fungsi dan bahanbahan yang digunakan sudah tidak sesuai dengan aslinya, banyak terjadi perubahanperubahan baik itu dari segi fungsi, bentuk maupun bahan-bahan yang digunakan oleh masyarakat. Perbedaan pemanfaatan Siring pada waktu terdahulu/awal pembuatan rumah dan pada waktu sekarang dapat dilihat perubahan-perubahan yang terjadi dikarenakan faktorfaktor yang ada. Secara keseluruhan masyarakat lebih mengarah kepada fungsional dari Siring itu sendiri, seperti halnya tempat beristirahat, tempat buang hajat dan lain-lain.Masyarakat tidak lagi berpedoman kepada filosofi budaya yang diajarkan oleh nenek moyang mereka.

Faktor-faktor yang mempengaruhi terjadinya perbedaan dan perubahanpemanfaatan antara lain:

\section{Ekonomi}

Analisis penulis dari hasil wawancara dan observasi menyimpulkan, masyarakat akan melakukan perubahan/perbaikan secara bertahap terhadap ruang siring jika kemampuan ekonomi mereka di atas rata-rata atau mencukupi untuk membeli bahanbahan yang akan digunakan seperti batu bata, semen, tegel dan lain-lain. Namun ada juga beberapa dari mereka yang lebih memperhatikan faktor fungsi dan bahan-bahan yang digunakan tidak harus yang berbayar, mereka masih bisa mendapatkan bahan-bahan yang alami.

\section{Sosial}

Dari hasil wawancara terhadap sampel jika ditinjau dari aspek sosial masyarakat, menurut narasumber yang menjelaskan, sekarang ini status sosial tidak lagi mengacu pada tradisi orang-orang terdahulu melainkan kepada tingkat kesejahteraan masyarakat itu sendiri dilihat dari segi mata pencaharian, sehingga semakin kita sukses maka semakin bagus pula rumah kita dan tidak lagi mengacu pada aturan-aturan adat yang menurut 
narasumber hal tersebut membatasi hak-hak mereka dalam kebebasan membangun atau memperbaiki rumah mereka, narasumber juga menyadari bahwa hal tersebut sudah menyalahi aturan-aturan adat yang ada.

\section{Budaya}

Faktor lain yang mempengaruhi terjadinya perbedaan dan perubahan pemanfaatan siring pada rumah tradisional Bugis-Makassar di Bulukumba adalah faktor budaya yaitu adat istiadat. Analisis penulis dari dari hasil wawancara terhadap narasumber pemilik sampel menjelaskan bahwa faktor budaya dalam hal ini adalah adat istiadat yang sudah tidak lagi menjadi acuan bagi mereka dalam menjalankan aktivitas sehari-hari atau melakukan suatu kegiatan yang berkaitan dengan kolong rumah (siring) tapi lebih kepada fungsional dan kebutuhan saja.

\section{KESIMPULAN}

Kolong rumah (siring)pada rumah tradisional Bugis-Makassar di Bulukumba saat ini tidak luput dari perubahan baik itu secara wujud, fungsi maupun tatanannya. Bergesernya budaya atau akibat perkembangan zaman yang begitu kuat mengakibatkan pemikiran masyarakat yang awalnya berpedoman kepada budaya-budaya/kepercayaan leluhur mereka kini lebih mengarah kepada perkembangan zaman modern dalam hal ini yang berkaitan dengan bentuk dan fungsi pada kolong rumah (siring). Masyarakat dulunya beranggapan bahwa kolong rumah (siring) tidak difungsikan sebagai tempat untuk ditinggali karena menurut pemahaman mereka tempat tersebut di peruntukan untuk hewan ternak dan tempat yang kotor.Namun saat ini masyarakat tidak lagi berpedoman kepada filosofi budaya yang diajarkan oleh nenek moyang mereka tetapi secara keseluruhan masyarakat lebih mengarah kepada fungsional dari siring itu sendiri, seperti halnya tempat beristirahat, tempat bekerja dan lain-lain. Perbedaan dan perubahan yang terjadi pada siring karena adanya faktor-faktor tertentu yang menyebabkan hal tersebut terjadi seperti faktor ekonomi, sosial, dan budaya. 


\section{DAFTAR REFERENSI}

Debby, T. R., \& Dewi, S. P. (2019).Transformasi Sosio-Spasial Kawasan Pecinan Kota Semarang.Jurnal Pengembangan Kota, 7(1), 46. https://doi.org/10.14710/jpk.7.1.46-56

Dewi, N. M. E. N. (2014). Transformasi Pemanfaatan Ruang Komunal Pada Permukiman Tradisional Bali Di Desa Pekraman Pedungan.Jurnal Space, 1(1), 42-50.

Emmanuel Arenibafo, F. (2017). The Transformation of Aesthetics in Architecture from Traditional to Modern Architecture: A case study of the Yoruba (southwestern) region of Nigeria. Journal of Contemporary Urban Affairs, 1(1), 35-44. https://doi.org/10.25034/1761.1(1)35-44

Hatta, A. J., \& Sudradjat, I. (2020).Peran sanro bola dalam tradisi membangun rumah tradisional Bugis di Kabupaten Soppeng. ARTEKS: Jurnal Teknik Arsitektur, 5(1), 63-72. https://www.journal.unwira.ac.id/index.php/ARTEKS/article/view/119

Nurhuzna, A. (2017). Transformasi Fungsi Dan Bentuk Arsitektur Bugis-Makassar Di Pesisir Pantai Buti Merauke. Jurnal Ilmiah Mustek Anim Ha, 6(2), 193-203.

Soewarno, N. (2020). Pola Pergeseran Fungsi Hunian Pada Bangunan Rumah Toko Kasus: Transformasi Bangunan Di Kawasan Pasar Baru-Bandung. Jurnal Arsitektur ZONASI, 3(2), 113-124. https://doi.org/10.17509/jaz.v3i2.25374

Ching, F. D. K. (1979). Arsitektur: Bentuk, Ruang dan Susunannya. Penerbit Erlangga. Jakarta.

Moleong, Lexy J. (1994). Metodologi Penelitian Kualitatif. Bandung: Remaja Rosdakarya.

Selia Stefi Yuliasari. (2010). Fungsi Dalam Arsitektur. http://selia-stefi.blogspot.co.id. Diakses pada tanggal 25 oktober 2015.

Tato, Syariar. (2009). Arsitektur Tradisional Sulawesi Selatan Pusaka Warisan Budaya Lokal Indonesia. El Shaddai: Makassar.

Tato, Syariar. (2013). Rumah Tradisional Sulawesi Selatan. El Shaddai: Makassar.

Zulkarnain AS, Andi Hildayanti."Integrasi Konsep Arsitektur Islam Pada Rumah Adat Saoraja Lapinceng Di Kabupaten Barru." Nature : National Academic Journal of Architecture 5, no. 1 (2018): 1-12.

Zulkarnain AS, Mutmainnah. "Lokalitas Struktur \& Material Konstruksi Rumah Adat Sapo Battoa Desa Kaluppini, Kabupaten Enrekang, Sulawesi Selatan." Nature : National Academic Journal of Architecture 4, no. 1 (2017): 74-82.

Zulkarnain AS. "Rumah Adat Sappo Lalanan Kaluppini Kabupaten Enrekang." Nature: National Academic Journal of Architecture 5, no. 2 (2018): 94-104.

Zulkarnain AS. "Wujud Arsitektural Rumah Tradisional Duri Asli di Kabupaten Enrekang." Nature: National Academic Journal of Architecture 2, no. 2 (2015): 130-37. 